\title{
ВОСТРЕБОВАННОСТЬ МЕТОДОЛОГИИ СОЦИАЛЬНОГО ПОЗНАНИЯ
}

\author{
(c) 2018 Мостовая Ирина Владимировна
}

доктор социологических наук, профессор, главный научный сотрудник Высшей школы бизнеса

Южный федеральный университет

344019, г. Ростов-на-Дону, ул. 23-я линия, д. 43

E-mail: mostovaya@sfedu.ru

Статья посвящена анализу востребованности методологического поиска при исследовании изменений социальной реальности. Рассматриваются взаимосвязи идентичности и маргинальности, семантической трансляции культурного кода в процессе генерационных сдвигов, тектоники изменений в образе жизни под влиянием технологической революции.

Ключевые слова: методология социологии, общество, социальная идентичность, культура, образ жизни.

Наверное, каждому поколению в современном обществе кажется, что оно живет в «эпоху перемен». И социальные философы стараются осмыслить изменения, рассуждают о них, делятся своими наблюдениями и выводами. Социологи, напротив, спешат сделать столь нужные для экономической практики и общественного управления замеры, но не всегда их глубоко и тщательно обрабатывают, анализируют, публикуют. Даже если это получается (как правило, в продолжительных коллективных исследованиях крупных проблем), результаты описываются специальным научным языком, иногда непостижимым не только для междисциплинарного научного оборота, но и для представителей других методологических платформ социологии, хоть в этом и не принято признаваться. В любом случае, выводы социологов проникают в социальный дискурс и практики отрывочно, фрагментарно, а эпистемология социального познания не очень заметно влияет на социологическую эвристику.

Влияние современной российской социологии на общественное сознание также не очень велико, в нем расплавлены некие туманные (но как бы ясные и строгие по содержанию, опорные для вынесения суждений, при этом бесконечно далекие от критерия «лумановской границы») понятия: традиционные ценности, глубокое социальное расслоение, модернизация, общественный договор, наши люди, гражданское общество, маргиналы. Этот замечательный «инструментарий» для описания, объяснения и прогнозирования изменений социальной реальности сам по себе довольно скуден, да и не отражает важных взаимосвязей между состояниями и действиями. И причина, как ни странно, в методологии - ведь именно она определяет принципы познания, порождает системные теоретические подходы и языки описания, в терминах которых заключены «связные» (глубинные, соединяющие понятия и явления друг с другом) [1] социальные смыслы.

Потребность в развитии методологии социального познания, пусть неотчетливо выраженная и робко себя проявляющая - достаточно просмотреть результаты поиска по профильным издательствам, журналам, исследовательским институтам - уже давно не кабинетная, стремящаяся соединить в своей научной потребности запрос как на гносеологию, так и на алгоритм, вполне обоснована теми тектоническими движениями, которые определяют актуальные тренды развития общества.

В обоснование этого тезиса так и тянет пойти с конца: от ситуативных событий к фундаментальным основаниям социальной динамики и собственно теории. Совсем недавно предметом весьма возбужденного общественного обсуждения стала граница пенсионного возраста россиян. Высказались политики, законодатели, эксперты, сообщества работодателей, профсоюзы; гражданские активисты организовали протестные шествия и митинги; решение о повышении пенсионного возраста было принято. Социологи многократно замеряли отношение россиян к проблеме в разрезе регионов проживания респондентов, возрастных, гендерных и профессиональных групп, выявляли несогласие, отрицание, депривацию. Эксперты-экономисты в зависимости от общего подхода обосновывали либо фундаментальную необходимость повышения пенсионного возраста, либо, напротив, 
возможность избежать этого, ссылаясь как на демографические тренды, так и на бюджетный профицит и наполнение общественных фондов, способных поддерживать бездефицитность ПФР. Однако в общественном дискурсе отсутствовали смысловые единицы, позволяющие глубоко и рационально говорить о социальной защите старости, трудовых правах граждан и обязанностях государства, принципах делегирования свободы гражданина в определении своих жизненных перспектив и накапливаемых материальных ресурсов в старшем возрасте, принципов построения пенсионной системы и технологий решения проблем пенсионирования, способах достижения целей в экономике пенсионного обеспечения.

Социологи не стали заметны ни в прояснении смысла и сути общественного договора, ни даже в обосновании того простого следствия повышения возраста выхода на пенсию для женщин, которое приведет к разрушению опорного социального института, «естественным» (габитуализированным) порядком замещавшего важные направления социальной работы в обществе. Конечно, я имею в виду участие в воспитании внуков и помощь престарелым родителям. Мы наблюдаем развитие социального бизнеса и государственных сервисов дополнительного образования детей, патроната пожилых людей и т.п., однако не можем не предполагать, опираясь на экспертные оценки, некоторого обвала в этих двух плоскостях полезной социальной активности «молодых пенсионерок», которые и так всю жизнь несут второе и третье бремя домоводства и воспитания детей помимо труда в общественном производстве. До общественного сознания докричались только социальные демографы, апеллирующие к продолжительности жизни мужчин и куцему периоду пенсионного дожития.

Чтобы правильно выступить в общественной дискуссии, мало сформулировать позицию, надо ее обосновать. А наши исследования структуры обыденной жизни как будто табуированы или же выхолощены их теоретические платформы: не описаны бюджеты времени (разве что только для отдельных групп молодежи), гендерные роли, социальные функции активного населения, трудовые этосы, субкультуры (кроме ювенально девиантных), реальные социальные сети (в которые включены люди, обменивающиеся деятельностью, а не только информацией через интернет).

А молодежь, которая неожиданно стала проявлять некие протестные порывы? Аполитичная и конформная, гиперпатерналистичная и социально инертная [2], она предстала как акционистски мерцающий фантом, заряженный неизвестной энергией и страшащий непросчитанным потенциалом активности и неизвестностью вектора. Очень мало социологических исследований общественных генераций [3], в которых мы находим отчетливые установки поиска методологии изучения общественной транзиции в поколениях.

Еще один актуальный пласт социологических исследований, с очень проблемным уровнем теоретизирования и методологического обоснования - национальные и религиозные общности в современном гражданском обществе, их культурные границы, взаимодействия, взаимопроникновения и конфликтный потенциал. На текущем этапе трудно даже представить спокойную, глубокую, неполитизированную проработку этой предметной области на добротной теоретико-методологической основе, а между тем ее научная и практическая ценность в современном российском обществе беспримерно велика. Сложность состоит отнюдь не в квалификации исследователей, а в эмоционально неровном, насыщенном разнообразными стигматизаторами общественном дискурсе, который неизбежно влияет и на рациональность анализа, и на общественную презентацию научных результатов.

Не вследствие, но рядом и связно стоит проблематика «места России в мире», которая, помимо политических позиций западничества, условного почвенничества и выбора особого пути - опирается в социологии на теории глобализации и нации (национального государства), а описывается в терминологии стратегий общественного развития. Ее полуинструментальным приложением является теория модернизации и наличия/возможности моделей общественного заимствования, которые все глуше обсуждаются в специальной литературе, хотя мы не находим в ней и теоретико-методологических обоснований культурного, социального изоляционизма либо экономической автаркии. Но то, что на макроэкономическом языке именуется «встраиванием в технологические цепочки международного разделения труда» на социологическом языке не формулируется и исследователь не 
озадачен ни простыми, ни многослойными размышлениями о человеке в модернизированном обществе и современном мире.

А между тем этот мир становится все более экономически, технологически, культурно и коммуникативно связным и в силу порядка величин довлеющим на ход определенных социальных активностей и общественных динамик национального уровня. Мы имеем в виду не только формирующиеся тренды больших процессов, мощно втягивающих в свою «орбиту» динамические элементы национально-хозяйственных систем (международные рынки, международные экономические специализации, международную финансовую инфраструктуру, крупные торговые и таможенные союзы и т.п.), но и постоянно развивающуюся сеть надгосударственных институтов, обладающих самостоятельным влиянием системного характера,- а также собственно культурный процесс в его аксиологическом и семантическом аспектах, вовлекающий современного человека в определенную систему ценностных координат, способы и языки информационного обмена.

Переходя от констатации того, что мы живем в быстро развивающемся мире, в котором происходит уже вторая на жизни текущего поколения информационная революция, а биотехнологии, прикладная генетика, роботизация, искусственный интеллект и многие другие векторы научно-технического развития уже прямо влияют на формирование структуры, связей и динамику современного общества, к более частным и «простым» вопросам: например, о взаимодействии активных поколений - мы сразу обнаруживаем, что внутри национального общества резко дифференцирована включенность в глобальный процесс в генерационном, профессиональном, поселенческом срезе. И что бы мы ни взяли: голосование по Брекзиту или наше собственное отношение к пенсионной реформе - мы находим новые и часто неожиданные ареалы солидарностей, которые ставят свой теоретико-методологический вопрос.

Тут мы подходим к более фундаментальным социологическим конструкциям, частным воплощением которых являются электоральные предпочтения и политическая активность, экономическое поведение, духовная общность и готовность на ее основе действовать сообща, или, по крайней мере, сходным образом (частным проявлением чего ныне нередко выступает флешмоб). А именно, неизбежно начинаем размышлять о социальной идентичности и о том, какие она порождает статусы, объединения и поведение.

Из общей социологической теории следует, что нестабильные (динамичные) периоды развития общества порождают дисфункцию социальных институтов, когда они частично разрушаются и структурно-функционально трансформируются, при этом общественные установления (правила, практики, привычки и нормальности в общепринятом смысле) а также ценности, в первую очередь, порядка (должного) нарушаются и ставятся под сомнение участниками общественных отношений. Вместе с объективными границами порядка, в который общество вкладывает огромный объем ресурсов - от материальных до организационных профессионально-квалификационных - становятся субъективно зыбкими границы причисления человека к группам и обществу в целом. А это, как последовательно рассуждает любой социолог, порождает маргинальность.

Мы наблюдаем признаки социальной маргинальности и маргинализации во многих общественных явлениях и процессах, это, в общем-то, обычное явление в живой ткани общества, если не переходит здоровых границ. Внедрение технологий, появление инноваций, изменение потребностей, личный выбор - эти и другие причины могут сдвинуть субъекта на периферию системно-сетевых связей, проявляться в выталкивании или самоотчуждении, стремлении покинуть общность и найти свой новый круг.

Идентичность в социальном плане редко претерпевает «крушение», но расщепление идентичности между разными планами причисления/принятия/отнесения каждый раз порождает маргинальные состояния, как и институциональный кризис, разрушающий социальную позицию и требующий адаптации человека через посредство смены идентичности. Мы всегда говорим о том, что социальная идентичность субъективно проявляется в причислении человеком себя к некой общности (маленькой или большой, от брака до гражданства или религиозного самоопределения). Это необходимое, но не достаточное условие. Сообщество тоже должно счесть человека своим членом, принять его и поддерживать, подтверждать его групповую идентичность. Если между этими двумя условиями происходит разрыв, полный или частич- 
ный, - наступление маргинальных состояний (как, к примеру, у представителей русского мира за рубежом) практически неизбежно: либо человек себя к группе уже не причисляет, а группа считает его своим и репрессирует инструментами стимулирования и нормативного контроля, либо человек себя с данной группой идентифицирует, а она слабо подтверждает его причисление и реальное принятие, вовлечение.

Методологическая эвристика учета этой закономерности представляется очевидной в анализе молодежи, трудовых отношений, даже гражданства.

Расщеп идентичности в социальном смысле возможен и на другом уровне, где ингрупповое причисление может не подтверждаться признанием группового членства человека аутгруппой - то есть людьми, которые сами в эту общность не входят, но считают некоторых людей членами данной группы. Ну, и поскольку уровней причисления три, возможны комбинации расщеплений идентичности, порождающие маргинальные состояния разного характера. $\mathrm{K}$ сожалению, теоретические возможности исследовать разнообразные социальные состояния, выявляя и объясняя их через идентификационные комплексы, не часто используются.

И в заключение хотелось бы заметить, что, несмотря на то, что современная социология очень «культурологична», и это совершенно справедливо, если верить Р. Докинзу, который сформулировал идею о постгенетической эволюции человека на основе трансляции культурных кодов, мы все еще ожидаем фундаментальные социологические работы, описывающие и объясняющие реальность с позиций социального культурогенеза. Будем надеяться, что они вскоре появятся и помогут найти социально значимые ответы.

\section{Библиографический список}

1. См.: Куликов С.Б. Основы философского анализа науки: методология, смысл и цель. Томск, 2005; Ушаков Е.В. Философия и методология науки. Москва. 2017.

2. См., напр.: Горшков М.К., Шереги Ф.Э. Молодежь России: социологический портрет. Москва. 2010; Новое поколение. Всероссийское репрезентативное исследование молодежи 16-26 лет. ФОМ. Москва. 2009; Контрреволюция молодежи: от чрезмерный амбиций к прагматизму. Москва. 2007; Поколение XXI: структура и среды достижительных технологий. Москва. 2008 и др.

3. См., напр.: Герасимов Г.И. Трансформация образования - социокультурный потенциал развития российского общества / Отв. ред. Ю.Г. Волков. Москва. 2005; Луков В.А. Концептуализация молодежи в XXI веке: новые идеи и подходы // Социологические исследования. 2012. № 1. 